\title{
The Sixth Technological Structure: Strategic Goals and Objectives for Restructuring the Global Economy in the Conditions of Recession and Economic Instability
}

\author{
Andrey Sosnilo \\ Department of Management \\ Saint Petersburg branch of the Financial University under \\ the Government of the Russian Federation \\ Saint Petersburg, Russian Federation \\ E-mail: a_sosnilo@mail.ru \\ Mikhail Kreer \\ Foreign Languages Department \\ Saint Petersburg branch of the Financial University under \\ the Government of the Russian Federation \\ Saint Petersburg, Russian Federation \\ E-mail: mkreer@mail.ru
}

\begin{abstract}
This article is devoted to the economic policy, the analysis of the concept "technological structure", understanding issues of innovative development, the role of innovations in the development of different countries during different historical eras. There are also historical parallels of innovations impact on the countries development in different historical periods; in particular this article reveals the essence of the significant economic growth that was experienced Holland. An example of the perception of ideas in the electrification of the USSR in the West and our modern perception of ideas of gradual transition to renewable energy in developed countries is given here. Suggestions are the following: to invest in the creation of NWF modern enterprises and their subsequent privatization (sale), return on invested funds for the creation of new businesses, and investment into agricultural revival.
\end{abstract}

Keywords - technological structure; innovation; development strategy; investment; neoindustrialization; industry

\section{INTRODUCTION}

Historical studies present a school of thought where the human history is regarded as the history of introducing and implementing innovations which provided societies with the competitive edge and expanded their living space. Among those innovations are a variety of inventions from a stone axe, bow, cannon ball, wheel, plough, arbalest, gunpowder to nanotechnology, genetic engineering, robotics and the like.

\author{
Ekaterina Solovyeva \\ Faculty of financial and economic progress \\ Saint Petersburg branch of the Financial University under \\ the Government of the Russian Federation \\ Saint-Petersburg, Russian Federation \\ E-mail: eosolovyeva@fa.ru \\ Elena Zorina \\ Foreign Languages Department \\ Saint Petersburg branch of the Financial University under \\ the Government of the Russian Federation \\ Saint Petersburg, Russian Federation \\ E-mail: makyelena@rambler.ru
}

Innovations that change the world appear rarely and are called radical. This partly results in the fact that the economic development of mankind has had an intermittent nature (the leading edge of technology) although more advanced research tools help to accelerate breakthroughs.

At the beginning of the 20th century the author of the term "innovation", (the outstanding Austrian economist Joseph Schumpeter) explained his view that the business cycle development is based on the intermittent nature of introducing innovations. He asserts that the source of innovative waves is accumulated knowledge.

\section{TeChNOlOGical Structure - A VIEW From the PAST}

Modern science reveals the term "technological structure" as a combination of applied technologies typical of the definite production growth rate. This term was introduced in science by the Russian economists D. S. Lvov and S. Yu. Glazyev [1].

Technological structures exist for certain periods and succeeds one another. In various countries the succession of technological structures can happen in different timeframes. The lifecycle of a technological structure is the period of its dominance in the global or local GDP.

In human history there are six technological structure, starting with the Industrial Revolution in the 18th century. Now the sixth technological structure is being formed, which includes nanotechnologies, genetic engineering, 
cellular technologies, artificial intelligent systems, worldwide information network, etc.

The lifecycle of a technological structure can have a different rate, but on average it can be limited to one century. The period when a certain technological structure dominates in economic development is nearly $40-50$ years long and the acceleration of technological progress leads to the period being gradually reduced.

The previous technological structure was based on microelectronics. Production of electronic products was 1260 per capita in the USA, 500 in the EC [3].

To S. Yu. Glazyev's mind, the core of the technological structure is Nano electronics, molecular Nano photonics, Nano materials, Nano structured covers, Nano biotechnology, and Nano system equipment. S. Yu. Glazyev predicts that the advantage of the technological structure, to compare with the previous one, will be a sharp decrease in energy output and materials-output ratio as well as materials and goods designing with improved properties and features.

\section{Global Competitive EdGE ON THE CivilizATION'S LEVEL}

Here we see the term of global competitive edge on the civilization's level. Once one of small European countries changed into commonwealth with the powerful fleet, because it began to convert wind energy in windmills into forward movement. This allowed the country to use sawmills and produce 20 ships a year - instead of two previously - and to process a large number of different goods - this will be described below.

Of the 20,000 ships used around the world 16,000 were built in Holland (or $80 \%$ of all ships). In the period of prosperity from 1664 to 1678 the Dutch merchant marine included 20,000 ships.

Karl Marx wrote in The Capital: "In 1836, 12,000 windmills of 6,000 horse-power were still operating in Holland, to prevent two-thirds of the land from being reconverted into morasses" [4].

These modified seventh century Persian inventions were applied in Holland for water supply and land drainage, set machines and equipment into motion in sawmills and were used to make butter (creameries), paper, sails, and black oakum. Windmills helped to grind corn, mustard and spices, and to make paint and snuff tobacco.

Before that sawing logs into wood boards was the hardest manual labor which was challenging and time consuming; it was impossible to produce on a large scale, to levigate solid minerals for making paint, flour and butter. Everything changed when making and processing of goods began to use wind power in the thirteenth century. The Dutch were able to increase output, quality and speed of production, to cut costs - which gave an opportunity to develop home construction - shipbuilding, textile manufacturing, products making and so on all increased in dramatically in production; such examples are numerous.
In 1920 the Russian electrification plan was designed or the GOELRO plan - which was based on Lenin's message "Communism is Soviet power plus the electrification of the whole country".

In October 1920 Herbert Wells, the famous writer of science fiction, visited V. I. Lenin. On Leaving Russia, H. Wells published the book Russia in the Shadows. He wrote that Lenin "has succumbed at last to a Utopia, the Utopia of the electrifications. He is throwing all his weight into a scheme for the development of great power stations in Russia to serve whole provinces with light, with transport, and industrial power. Two experimental districts he said had already been electrified. Can one imagine a more courageous project in a vast flat land of forests and illiterate peasants, with no water power, with no technical skill available, and with trade and industry at the last grasp?" [5].

Such electrification projects could be implemented in Holland, England, Germany, but the writer could not see the future Russia in this regard, unlike V.I. Lenin. Lenin described to him the disappearance of destroyed railways and the appearance of new electrified motorways which could revive the whole country and also saw the country becoming modernized and an industrialized commonwealth on the rise. The objective was implemented as follows: the number of power plants increased from 33 to 858, the installed capacity from $712 \mathrm{kWh}$ up to $18,500 \mathrm{kWh}$, and the current consumption from $427,000 \mathrm{kWh}$ up to 10,000,000 kWh all this from the year 1913 to 1927.

As OPEC's and CIA's statistics and estimates say, Saudi Arabian petroleum reserves are evaluated to be 262 billion barrels. According to the current oil production, the reserves will be supplied in the next 72 years. Venezuela's reserves, 211 billion barrels, will meet demand in the coming 234 years. Canada is also in Top 3: 175 billion barrels will hold out for the next 26 years. Then there come Iran and Iraq whose reserves will be sufficient for the coming 88 and 128 years respectively. The sixth place is occupied by Kuwait whose "black gold" will hold out only for 11 years.

Russian oil reserves, as WOC estimates, are on the level of 60 billion barrels. They could meet demand in the coming 21 years. Now we can also evaluate 100 billion reserves discovered in the Kara Sea in 2014.

Libya stands in ninth place (with 46 billion barrels for 77 years) and Nigeria is also in Top 10 (with 37 billion barrels for 42 years) [6].

During a 19 years span the Soviet Union, under the command of I. V. Stalin, increased industrial production 70 fold. From the level of one of the least developed countries to becoming a global leader. Within 26 years the Soviet Union managed to increase industrial production more than 20 times, despite the devastating effects of World War II which caused a great deal of economic loss.

In 1990 the GDP in China represented approximately 404 billion dollars and was 1.4 times lower than the GDP in the Soviet Union (\$569 billion); in 2012 the GDP in China equaled $\$ 8,358$ billion. 


\section{Alternative SOURCES OF ENERGY}

The trend that could hypothetically provide more independence and fewer expenses on energy costs is called alternative energetics. If we compare it with traditional forms of energetics, we can conclude that the present-day level of technologies does not give an opportunity to cut more costs on a commercial scale, but potentially in the future, the rise in COP and operating costs can improve the current situation significantly.

In order to achieve this goal in the next 20-30 years, it is necessary to invest more in this economic sector.

Presently, there are dramatic changes in this regard in many countries. Alternative energetic share in Germany is predicted to increase from $20 \%$ now to $80 \%$ in 2050 . By 2022 all nuclear power plants will be decommissioned. Taking into consideration the Germans' persistence, meticulousness and superb engineering ideas, only the timeline can be somehow questioned.

The USA also has taken active measures to gradually reject using exhaustible energy sources, meanwhile to partly bring back into service their own supplies of hydrocarbons and to implement programs of slate extraction. As one of the largest oil-importing countries, the USA published the following report "American Energy: The Renewable Path to Energy Security". The governor of New York State Andrew Cuomo announced the start of business operations for the bank which will provide funds to projects aiming at lending connected with development of clean energy systems. The initial capitalization for the Green Bank amounted for one billion US dollars will rise annually from thereon.

For a long time already the emirate of Dubai has been investing its oil and gas revenues in tourism and business infrastructure, property, various high-technology projects (from telecommunications to the photovoltaic power station "Solar park") and creating successful free trade zones. Although such policy has some disadvantages, it enables it to reduce the level of the emirate's dependence on its oil revenues every year.

\section{THE NECESSITY OF INNOVATIONS AT THE CORPORATE AND STATE LEVELS}

Economy without planning and government regulation is like an infant before an open window. The infant is unaware of the danger of height and does not feel it. Records of accidents and incidents report that such a situation often has tragic results.

Every major corporation like Intel, Microsoft, Samsung, Apple, Huawei or Google requires innovations to be marketed. Only constant design and implementation of innovations help organizations be the first to enter the market with new products, meet the competitive edge, update technologies, and cut operating costs.

In recent years the number of technological clusters and business incubators has risen, a lot of programs to support business and youth initiatives have also appeared. However, the global research done recently states that there are only 5-7\% of businesslike people.

State-of-the-art technologies are used in developing and producing armament and thus can become dual technologies, it means they can be applicable to social life as well. If we analyze trends and forecasts of military industry development, we find thousands of armed drones with the elements of artificial intelligence and armory registered in the USA in 2013. As Robert Cone (General of the US Army) claims, about $25 \%$ of troops will have been supplied with robots by 2030 .

Since 2008 the USA has begun to attack Pakistan with drones. As a result of the missile attacks, there has been 1,100 death recorded, including some guerrilla leaders, but among the victims there were civilians as well.

In September 2010 the missile fired by the drone Predator destroyed the car of the Egyptian sheikh Al-Fatah. He was presumably the leader of al-Qaeda in Afghanistan and Pakistan. The past leader Mustafa Abu al-Yazid had also been killed by a drone missile attack in May of 2010 . This fighting experience makes it evident that using drones and robotic technology can lead to severe consequences.

The authors came to the conclusion about exceptional significance of the new technological wave for developing the most fields of industry, emerging new features of the existing goods, which are supposed to be capable of having great impact on the existing competitive environment due to nanotechnology.

\section{CONCLUSION}

Nowadays, implementing innovation is one of the most important roles in economic development of some sovereign states. However, the fact that most western companies from different fields of industry were transferred to South-east Asia gave an excellent opportunity for a number of Asian companies to bridge technological gaps, with the periods of production output being dramatically reduced. Moreover, in some fields they manage to outstrip their western counterparts.

This has led to reducing both lifecycle of technologies and pay-off periods to make profit.

Along with this the transition to a new technological wave, automated manufacturing increases unemployment rate which with a long-term prospective would escalate social tension.

Therefore, it's absolutely indispensable to work out a well-balanced solution taking into account both economic factors and public interests.

\section{REFERENCES}

[1] Glaz'ev S. The strategy of advanced development of Russia during the global recession : monography.

[2] Lessons of Russian Revolution: Liberal Utopia Crisis \& Chance for Economy Miracle. M.: Jekonomicheskaja gazeta, 2011.

[3] Vladimir Putin Speech to Federal Parliament (Stenogram) 
[4] Karl Marx. Capital A Critique of Political Economy. Volume I Book One: The Process of Production of Capital. - Volume I. - M.: 2013.

[5] Wells H. M., Russia in the Shadows. M.: 1964. - Volume 15. - pp. 313-376. - 463 p.

[6] Zhuravleva N. It will be Enough for Our Century //The newspaper «Vzgljad». - 02.11.2012.

[7] Illarionov A. Main Development Trends of Global Economy in Second Half of 20s Century - Voprosy jekonomiki. (Economic issues) № 10/97. - pp. 117-148. 